\title{
CITRA MEREK, KEPERCAYAAN MEREK DALAM MEWUJUDKAN LOYALITAS MEREK PRODUK AQUA
}

\author{
Nurul Laela Sakinah ${ }^{1}$, Dadang Suhardi ${ }^{2}$ \\ 1,2 dadang.suhardi@ymail.com \\ ${ }^{1,2}$ Program Studi ManajemenFakultas Ekonomi Universitas Kuningan
}

\begin{abstract}
This research aims to find out the brand image and brand trust towards brand loyalty of AQUA product. The population of this research is the consumer of AQUA in Kuningan district and the data are collected by questionnaire technique. The purposive sampling technique is applied in this research while the sample of this research is 100 respondents using measurement scale of interval scale. The analysis method in this research is descriptive and verification with quantitative approach that cover validity and reliability, classic assumption test, hypothesis testing through $F$ test, $T$ test and determination coefficient $\left(R^{2}\right)$. The technique of data analysis is gained by the use of multiple regression linear. All tests on this research use a measured instrument in the form of computer program SPSS (Statistical Package for the Social Science) version 21.0. Based on the result of this research, it is concluded that the brand image has positive influence and significant towards brand loyalty; brand trust has positive influence and significant towards brand loyalty as well as both of brand image and brand trust have also positive influence and significant towards brand loyalty.
\end{abstract}

\section{Keywords: Brand Image; Brand Trust; Brand Loyalty}

\begin{abstract}
ABSTRAK
Penelitian ini bertujuan untuk mengetahui citra merek dan kepercayaan merek terhadap loyalitas merek produk AQUA. Populasi penelitian ini adalah konsumen AQUA di Kabupaten Kuningan dan data dikumpulkan dengan teknik kuesioner. Teknik purposive sampling diterapkan dalam penelitian ini sedangkan sampel penelitian ini adalah 100 responden menggunakan skala pengukuran skala interval. Metode analisis dalam penelitian ini adalah deskriptif dan verifikatif dengan pendekatan kuantitatif yang meliputi validitas dan reliabilitas, uji asumsi klasik, pengujian hipotesis melalui uji $\mathrm{F}$, uji $\mathrm{T}$ dan koefisien determinasi (R2). Teknik analisis data diperoleh dengan menggunakan regresi linier berganda. Semua tes pada penelitian ini menggunakan instrumen yang diukur dalam bentuk program komputer SPSS (Paket Statistik untuk Ilmu Sosial) versi 21.0. Berdasarkan hasil penelitian ini, disimpulkan bahwa citra merek memiliki pengaruh positif dan signifikan terhadap loyalitas merek; kepercayaan merek memiliki pengaruh positif dan signifikan terhadap loyalitas merek serta citra merek dan kepercayaan merek juga memiliki pengaruh positif dan signifikan terhadap loyalitas merek.
\end{abstract}

Kata kunci: Citra Merek; Kepercayaan Merek; Loyalitas Merek 


\section{PENDAHULUAN}

Banyaknya penduduk Indonesia yang menyadari pentingnya mengkonsumsi air minum yang lebih sehat serta praktis menjadikan suatu peluang bisnis. Banyaknya perusahaan-perusahaan baru dalam bisnis Air Minum Dalam Kemasan (AMDK) di Indonesia memperketat persaingan yang ada.

Berdasarkan Undang-Undang Republik Indonesia Nomor 8 Tahun 1996 tentang Perlindungan konsumen bertujuan:

a) Meningkatkan kesadaran, kemampuan dan kemadirian konsumen untuk melindungi diri

b) Mengangkat harkat dan martabat konsumen dengan cara menghindarkannya dari ekses negatif pemakaian barang dan / atau jasa

c) Meningkatkan pemberdayaan konsumen memilih, menentukan dan menuntut hak-haknya sebagai konsumen

d) Menciptakan perlindungan konsumen yang mengandung unsur kepastian hukum dan keterbukaan informasi serta akses untuk mendapatkan informasi

e) Menumbuhkan kesadaran pelaku usaha mengenai pentingnya perlindungan usaha sehingga tumbuh sikap yang jujur dan bertanggung jawab dalam berusaha

f) Meningkatkan kualitas barang dan / atau jasa yang menjamin kelangsungan usaha produksi barang dan / atau jasa kesehatan, kenya-manan, keamanan dan keselamatan konsumen

Persyaratan teknis industri dan perdagangan air minum dalam kemasan dapat menjamin mutu produk air minum dalam kemasan (AMDK) sesuai dengan Standar Nasional Indonesia (SNI) yang berlaku, serta dapat meningkatkan daya saing dalam rangka menciptakan persaingan usaha yang sehat sekaligus memberi perlindungan terhadap konsumen. AMDK adalah air baku yang telah diproses dan dikemas serta aman untuk diminum. Air baku itu sendiri yaitu air yang telah memenuhi persyaratan kualitas air bersih sebagai mana diatur dalam keputusan menteri kesehatan nomor 416/MENKES/PER/IX/1990 untuk diolah menjadi AMDK. (Keputusan menteri perindustrian dan perdagangan Republik Indonesia nomor: 705/MPP/Kep/11/2003 tentang: Persyaratan teknis industri air minum dalam kemasan dan perdagangannya). Pada dasarnya, AMDK diproses melalui 3 tahap yaitu: penyaringan, desinfeksi dan pengisian. Penyaringan dimaksudk-an untuk menghilangkan partikel padat dan gas-gas yang terkandung dalam air Desinfeksi bertujuan untuk membunuh bakteri patogen dalam air. Pengisian merupakan tahap akhir proses produksi dimana air dimasukkan melalui sebuah peralatan yang dapat melindungi air tersebut dari kontaminasi selama pengisian kedalam kemasan.(Lampiran Keputusan menteri perindustrian dan perdagangan Republik Indonesia nomor: 705/MPP/Kep/11/2003 tentang: Persyaratan teknis industri air minum dalam kemasan dan perdagangannya -Pedoman proses, mesin dan peralatan produksi Air Minum Dalam Kemasan).

Air minum adalah air yang melalui proses pengolahan atau tanpa proses pengolahan yang memenuhi syarat kesehatan dan dapat langsung di minum. Penyelenggara air minum adalah badan milik negara / badan usaha milik daerah, koperasi, badan usaha swasta, usaha perorangan, kelompok masyarakat dan / atau individual yang melakukan penyelenggaraan penyediaan air minum. Setiap penyelenggara air minum wajib menjamin air minum yang diproduksi aman bagi kesehatan. 
Air minum aman bagi kesehatan apabila memenuhi persyaratan fisika, mikrobiologis, kimiawi dan radioaktif yang di muat dalam parameter wajib dan parameter tambahan. Parameter wajib merupakan persyaratan kualitas air minum yang wajib diikuti dan ditaati oleh seluruh penyelenggara air minum; Untuk menjaga kualitas air minum yang dikonsumsi masyarakat dilakukan pengawasan kualitas air minum secara eksternal dan secara internal. Pengawasan kualitas air minum secara internal merupakan pengawasan yang dilaksanakan oleh penyelenggara air minum untuk menjamin kualitas air minum yang diproduksi memenuhi syarat. (Peraturan menteri kesehatan Republik Indonesia nomor 492/MENKES/PER/IV/2010 tentang persyaratan kualitas air minum).

Air minum dalam kemasan adalah air yang telah diproses, tanpa bahan pangan lainnya dan bahan tambahan pangan, dikemas serta aman untuk diminum. Air Mineral merupakan air minum dalam kemasan yang mengandung mineral dalam jumlah tertentu tanpa menambahkan mineral. Air Demineral merupakan air minum dalam kemasan yang diperoleh melalui proses pemurnian secara destilasi, deionisasi, reverse osmosis (RO). Air Mineral Alami merupakan air minum yang diperoleh langsung dari air sumber alami atau bor dari sumur dalam dengan proses terkendali yang menghindari pencemaran atau pengaruh luar atas sifat kimia, fisika dan mikrobiologi air mineral alami. (Peraturan menteri perindustrian Republik Indonesia Nomor : 49/MIND/PER/3/2012 tentang pemberlakuan SNI AMDK secara wajib.

Sebuah perusahaan perlu mempertahankan pelanggan yang ada sehingga tidak beralih pada perusahaan lain. Dengan adanya pelanggan yang loyal pada merek maka perusahaan akan bertahan pada persaingan yang ketat. Meskipun banyak perusahaan yang menghasilkan produk yang sejenis, konsumen yang loyal pada satu merek akan dapat membedakan. Hal tersebut menjadi sebuah keuntungan bagi perusahaan untuk memperkecil persaingan. Menurut Kotler \& Keller (2009: 259), Loyalitas merek memberikan tingkat permintaan yang aman dan dapat diperkirakan bagi perusahaan, dan menciptakan penghalang yang mempersulit perusahaan lain untuk memasuki pasar. Ketika akan membeli suatu produk konsumen akan mencari produk bermerek dengan citra merek yang positif, sebagai jaminan bahwa produk tersebut diharapkan akan memberikan yang terbaik. Sekarang ini konsumen lebih mencari produk dengan merek yang sudah terkenal. Dengan merek yang sudah terkenal, konsumen mengharapkan dapat memperoleh kualitas produk yang diberikan dan dapat menjadi citra yang baik sehingga konsumen akan percaya pada merek tersebut. Kepercayaan konsumen pada suatu merek akan membuat konsumen memiliki hubungan dengan merek tersebut. Dengan rasa percaya yang tinggi, konsumen akan dengan tinggi pula mengharapkan sesuatu yang baik, yang dapat dihasilkan dari merek tersebut.

Dari banyaknya merek produk yang dikeluarkan oleh perusahaan AMDK, Top Brand memberikan arti dalam persaingan tersebut.Bahwa dengan top brand menunjukkan suksesnya suatu merek dipasar. Berikut data Top Brand Index kategori AMDK: 
Tabel 1

Top Brand Index Kategori AMDK Tahun 2012 - 2015 Fase 2

\begin{tabular}{|c|c|c|c|c|c|c|c|}
\hline \multicolumn{2}{|c|}{$\begin{array}{c}\text { Tahun } \\
2012\end{array}$} & \multicolumn{2}{|c|}{$\begin{array}{c}\text { Tahun } \\
2013\end{array}$} & \multicolumn{2}{|c|}{$\begin{array}{c}\text { Tahun } \\
2014\end{array}$} & \multicolumn{2}{|c|}{$\begin{array}{c}\text { Tahun } \\
2015\end{array}$} \\
\hline $\begin{array}{l}\text { Me } \\
\text { rek }\end{array}$ & $\begin{array}{c}\text { TB } \\
\text { I }\end{array}$ & $\begin{array}{l}\text { Me } \\
\text { rek }\end{array}$ & $\begin{array}{c}\text { TB } \\
\text { I }\end{array}$ & $\begin{array}{l}\text { Me } \\
\text { rek }\end{array}$ & $\begin{array}{c}\text { TB } \\
\text { I }\end{array}$ & $\begin{array}{l}\text { Me } \\
\text { rek }\end{array}$ & $\begin{array}{c}\text { TB } \\
\text { I }\end{array}$ \\
\hline $\begin{array}{l}\text { AQ } \\
\text { UA }\end{array}$ & $\begin{array}{l}81, \\
0 \%\end{array}$ & $\begin{array}{l}\text { AQ } \\
\text { UA }\end{array}$ & $\begin{array}{l}81, \\
6 \%\end{array}$ & $\begin{array}{l}\text { AQ } \\
\text { UA }\end{array}$ & $\begin{array}{l}75 \\
2 \%\end{array}$ & $\begin{array}{l}\text { AQ } \\
\text { UA }\end{array}$ & $\begin{array}{l}75, \\
9 \%\end{array}$ \\
\hline $\begin{array}{l}\mathrm{CL} \\
\mathrm{UB}\end{array}$ & $\begin{array}{l}3,2 \\
\%\end{array}$ & $\begin{array}{l}\mathrm{CL} \\
\mathrm{UB}\end{array}$ & $\begin{array}{l}3,7 \\
\%\end{array}$ & $\begin{array}{l}\text { CL } \\
\text { UB }\end{array}$ & $\begin{array}{l}3,4 \\
\%\end{array}$ & $\begin{array}{l}\text { CL } \\
\text { UB }\end{array}$ & $\begin{array}{l}5,0 \\
\%\end{array}$ \\
\hline VIT & $\begin{array}{l}2,1 \\
\%\end{array}$ & VIT & $\begin{array}{l}3,1 \\
\%\end{array}$ & VIT & $\begin{array}{l}3,2 \\
\%\end{array}$ & VIT & $\begin{array}{l}2,6 \\
\%\end{array}$ \\
\hline $\begin{array}{l}\mathrm{AD} \\
\mathrm{ES}\end{array}$ & $\begin{array}{l}2,6 \\
\%\end{array}$ & $\begin{array}{l}\mathrm{AD} \\
\mathrm{ES}\end{array}$ & $\begin{array}{l}2,3 \\
\%\end{array}$ & $\begin{array}{l}\mathrm{AD} \\
\mathrm{ES}\end{array}$ & $\begin{array}{l}2,2 \\
\%\end{array}$ & $\begin{array}{l}\mathrm{AD} \\
\mathrm{ES}\end{array}$ & $\begin{array}{l}2,6 \\
\%\end{array}$ \\
\hline
\end{tabular}

Sumber : $\underline{\text { http://www.topbrand-award.com/ }}$

Berdasarkan tabel 1, dapat dilihat bahwa merek AQUA mengalami fluktuatif pada persentase top brand index.Persentase top brand index AQUA jauh lebih besar dari merek lainnya, hal tersebut menunjukkan bahwa AQUA memiliki citra merek yang baik bagi konsumen sehingga lebih banyak konsumen yang memilih produk Aqua daripada merek lainnya.

Tabel 2

Kinerja Merek (Brand Value) Kategori AMDK Tahun 2010-2012

\begin{tabular}{|l|c|c|c|}
\hline \multirow{2}{*}{ Merek } & \multicolumn{3}{|c|}{ Brand Value } \\
\cline { 2 - 4 } & $\mathbf{2 0 1 0}$ & $\mathbf{2 0 1 1}$ & $\mathbf{2 0 1 2}$ \\
\hline Aqua & 89,7 & 90,0 & 85,3 \\
\hline Ades & 36,7 & 40,1 & 27,5 \\
\hline Club & 41,7 & 40,2 & 27,3 \\
\hline Viro & - & - & 27,3 \\
\hline Vit & 37,6 & 40,1 & 27,2 \\
\hline
\end{tabular}

Sumber: SWA edisi 20/XXVIII/20 September-3 Oktober 2012

Tabel 2 menunjukkan bahwa kinerja merek AQUA mengalami fluktuatif, hal tersebut menunjukkan bahwa menurunnya ekuitas merek dan mempengaruhi pengelolaan merek, sehingga terjadi penurunan kepercayaan atau suatu merek. Dengan menurunnya kepercayaan merek akan berakibat pada pembeliaan yang rendah dan berpindah pada merek lain yang dilakukan oleh pelanggan.

Tabel 3

Indeks Loyalitas Pelanggan Kategori AMDK Tahun 2011 - 2012

\begin{tabular}{|l|c|c|c|c|c|c|c|c|}
\hline \multirow{4}{*}{ Merek } & \multicolumn{9}{|c|}{ Index } \\
\cline { 2 - 10 } & $\begin{array}{c}\text { Satisfacti } \\
\text { on }\end{array}$ & \multicolumn{2}{|c|}{ Loyalty } & \multicolumn{2}{|c|}{ Advocate } & \multicolumn{2}{|c|}{ ALSI } \\
\cline { 2 - 10 } & $\mathbf{2 0}$ & $\mathbf{2 0}$ & $\mathbf{2 0}$ & $\mathbf{2 0}$ & $\mathbf{2 0}$ & $\mathbf{2 0}$ & $\mathbf{2 0}$ & $\mathbf{2 0}$ \\
& $\mathbf{1 1}$ & $\mathbf{1 2}$ & $\mathbf{1 1}$ & $\mathbf{1 2}$ & $\mathbf{1 1}$ & $\mathbf{1 2}$ & $\mathbf{1 1}$ & $\mathbf{1 2}$ \\
\hline Aqua & 7,8 & 7,7 & 7,7 & 7,5 & 7,1 & 7,1 & 7,6 & 7,5 \\
\hline Vit & & 7,4 & & 7,4 & & 7,1 & & 7,3 \\
\hline Club & 7,7 & 7,5 & 7,4 & 7,3 & 6,9 & 7,1 & 7,4 & 7,3 \\
\hline
\end{tabular}

Sumber: Majalah SWA edisi 14/XXVIII/5-18 Juli 2012, SWA edisi 14/XXVII/7-17 Juli 2011

Tabel 3 menunjukkan bahwa pada merek AQUA terjadi penurunan pada kepuasan, loyalitas karena adanya perpindahan merek dan terjadi penurunan juga pada advokat, sehingga hasil akhir dari pengukuran tiga dimensi tersebut yaitu ALSI mengalami penurunan. Hal ini terlihat bahwa konsumen mulai berkurang tingkat loyalitas pada merek AQUA. Meski AQUA berada pada peringkat pertama Top Brand Index yang menunjukkan citra merek yang baik, namun kinerja merek AQUA mengalami fluktuatif sehingga kepercayaan konsumen pada merek AQUA berkurang, hal tersebut berpengaruh pada loyalitas merek AQUA. Dari permasalahan tersebut, peneliti tertarik untuk menjadikan Air Minum Dalam Kemasan merek AQUA sebagai objek penelitian dengan variabel yang diteliti adalah Citra Merek, Kepercayaan Merek dan Loyalitas Merek. Dengan tujuan untuk mengetahui pengaruh Citra Merek dan Kepercayaan Merek terhadap Loyalitas Merek. Penelitian ini sejenis dengan penelitian Rizan dkk. (2012), bahwa variabel brand image dan brand trust 
dapat mempengaruhi loyalitas pelanggan terhadap suatu merek.

\section{LANDASAN TEORI}

\section{Pemasaran Dan Manajemen Pemasa-} ran

Pemasaran adalah suatu proses sosial dan manajerial dari individu dan kelompok untuk memenuhi kebutuhan dan keinginannya melalui penciptaan, penawaran, dan pertukaran (nilai) produk dengan yang lain. Pemasaran adalah upaya menciptakan loyalitas konsumen terhadap produk yang ditawarkan (Saladin, Djaslim, 2006: 2).

Menurut Kotler \& Keller (2009: 5) inti dari pemasaran (marketing) adalah mengidentifikasi dan memenuhi kebutuhan manusia dan sosial. Salah satu definisi yang baik dan singkat dari pemasaran adalah "memenuhi kebutuhan dengan cara yang menguntungkan".

Sedangkan menurut American Marketing Association(AMA) dalam Kotler \& Keller (2009: 5) pemasaran adalah suatu fungsi organisasi dan serangkaian proses untuk menciptakan, mengomunikasikan, dan memberikan nilai kepada pelanggan dan untuk mengelola hubungan pelanggan dengan cara yang menguntungkan organisasi dan pemangku kepentingannya.

Menurut Kotler dalam Saladin, Djaslim (2006:4) Manajemen pemasaran adalah proses perencanaan dan pelaksanaan konsepsi, penetapan harga, promosi, dan distribusi gagasan, barang, dan jasa untuk menghasilkan pertukaran yang memuaskan individu dan memenuhi tujuan organisasi. Tujuan Manajemen pemasaran adalah untuk mempengaruhi tingkat, jangkauan waktu, komposisi permintaan, sehingga membantu organisasi mencapai sasarannya.

Menurut American Marketing Association (AMA) dalam Kotler \&
Keller (2009: 5) manajemen pemasaran terjadi ketika setidaknya satu pihak dalam sebuah pertukaran potensial berpikir tentang cara-cara untuk mencapai respons yang diinginkan pihak lain. Karenanya kita memandang manajemen pemasaran (marketing management) sebagai seni dan ilmu memilih pasar sasaran dan meraih, mempertahankan, serta menumbuhkan pelanggan dengan menciptakan, menghantarkan, dan mengomunikasikan nilai pelanggan yang unggul.

Pengertian pemasaran menurut Charles F. Philips and Delbert J. Duncan, (dalam Buchari Alma, 2013 : 1), marketing yang oleh para pedagang diartikan sama dengan distribusi dimaksudkan segala kegiatan untuk menyampaikan barang-barang ke tangan konsumen (rumah tangga) dan ke konsumen industri. Selanjutnya ditambahkan bahwa dalam kegiatan marketing itu tidak termasuk kegiatan perubahan bentuk barang yag kita jumpai di dalam Definisi dari Maynard and Beckman, Marketing berarti segala usaha yang meliputi penyaluran barang dan jasa dari sektor produksi ke sektor konsumsi.

D. Converse and Fred M. Jones (dalam Buchari Alma 2013 : 2) produksi diartikan sebagai pekerjaan menciptakan barang, sedangkan marketing ialah pekerjaan memindahkan barang-barang ke tangan konsumen.

Menurut William J. Shultz (dalam Buchari Alma 2013 : 2). Marketing atau distribusi adalah usaha / kegiatan yang menyalurkan barang dan jasa dari produsen ke konsumen. Sedangkan menurut Rayburn D. Tousley, (dalam Buchari Alma 2013 : 2). marketing terdiri dari usaha yang mempengaruhi pemindahan pemilikan barang dan jasa termasuk distribusinya Paul D. Converse. Harvey W. Huege, and Robert 
V. Mitchell, marketing didefinisikan sebagai kegiataan membeli dan menjual, dan termasuk di dalamnya kegiatan menyalurkan barang dan jasa antara produsen dan konsumen dan marketing terdiri dari kegiatan-kegiatan penciptaan kegunaan tempat, waktu, dan pemilikan

Manajemen Pemasaran menurut Philip Kotler and Amstrong (dalam Buchari Alma, 2013 : 130) , kegiatan menganalisa,merencanakan, mengimple mentasikan, dan mengawasi segala kegiatan (program), guna memperoleh tingkat pertukaran yang menguntungkan dengan pembeli sasaran dalam rangka mencapai tujuan organisasi. Selanjutnya William J. Shultz memberikan definisi manajemen marketing ialah merencanakan, pengarahan dan pengawasan seluruh kegiatan pemasaran perusahaan ataupun bagian dari perusahaan.

Ben M. Enis (dalam Buchari Alma 2013 : 130), Manajemen pemasaran ialah proses untuk meningkatkan efisiensi dan efektivitas dari kegiatan pemasaran yang dilakukan oleh individu atau oleh perusahaan, apabila seseorang atau perusahaan, ingin memperbaiki pemasarannya, maka ia harus melakukan kegiatan pemasaran itu sebaik mungkin. Dari pengertian tersebut mempunyai implikasi:

1) Menekankan adanya efektivitas dan efisiensi, efektivitas artinya memaksimalkan hasil yang hendak dicapai yang telah ditetapkanlebih dahulu, sedangkan efisiensi adalah meminimalkan pengeluaran atau biaya yang digunakan untuk mencapai hasil tersebut;

2) Manajemen pemasaran ini merupakan suatu proses, penekanan pada efisiensi dan efektivitas erat hubungannya dengan pengertian produktivitas. Ada pendapat yang menyatakan bahwa produktivitas adalah merupakan kombinasi antara efektivitas dan efisiensi. Jika orang ingin menentukan produktivitas, maka ia harus mengetahui hasil yang dicapai (ini masalah efektivitas), dan sumber-sumber apa yang telah digunakan (ini masalah penggunaan sumber-sumber seefisien mungkin (berdaya guna) dan mendapatkan hasil yang maksimal (berhasil guna), inilah efisiensi dan efektivitas.

\section{Perilaku Konsumen}

American Marketing Association (dalam J. Paul Peter, Jerry C.Olson 2013 : 6) mendefinisikan perilaku konsumen (customer behavior) sebagai " dinamika interaksi antara pengaruh dan kesadaran, perilaku, dan lingkungan di mana manusia melakukan pertukaran aspekaspek kehidupan" Dengan kata lain, perilaku konsumen melibatkan pemikiran dan perasaan yang mereka alami serta tindakan yang mereka lakukan dalam proses konsumsi. Hal ini juga mencakup segala hal pada lingkungan yang mempengaruhi pemikiran, perasaan, dan tindakan tersebut. Hal itu termasuk komentar konsumen lainnya, iklan, informasi harga, pengepakan, penampilan produk, blogs, dan lainnya. Perilaku konsumen yang bersifat dinamis, dan melibatkan interaksi dan pertukaran sangat penting untuk dikenali.

Menurut Engel et al (dalam Etta mamang sangadji, Sopiah, 2013 : 7), perilaku konsumen yang langsung terlibat dalam pemerolehan, pengonsumsian, dan penghabisan produk / jasa, termasuk proses yang mendahului dan menyusul tindakan ini.

Menurut Mowen dan Minor (dalam Etta mamang sangadji, Sopiah, 2013 : 7), perilaku konsumen adalah studi unit dan proses pembuatan keputusan yang terlibat dalam pener dalam penerimaan, penggunaan dan pembelian, dan penentuan barang, jasa dan ide. 
Schiffman, Kanuk (dalam Etta mamang sangadji, Sopiah, 2013 : 7) mendefinisikan perilaku konsumen sebagai "perilaku yang diperlibatkan konsumen untuk mencari, membeli, menggunakan, mengevaluasi, dan menghasilkan produk dan jasa yang mereka harapkan akan memuaskan kebutuhan mereka." Kotler (dalam Etta Mamang Sangadji, Sopiah, 2013 : 8), perilaku konsumen didefinisikan sebagai studi untuk pembelian dan proses pertukaran yang melibatkan perolehan, konsumsi dan pembuatan barang, jasa, pengalaman serta ide. Selanjutnya menjelaskan perilaku konsumen sebagai suatu studi tentang unit pembelian, bisa perorangan, kelompok, atau organisasi. Masingmasing unit tersebut akan membentuk pasar sehingga muncul pasar individu atau pasar konsumen, unit pembelian kelompok, dan pasar bisnis yang dibentuk organisasi.

Menurut Griffin (dalam Etta mamang sangadji, Sopiah, 2013 : 8) “ Perilaku konsumen adalah semua kegiatan, tindakan, serta proses psikologi yang mendorong tindakan tersebut pada saat sebelum membeli, ketika membeli, menggunakan, menghabiskan produk dan jasa setelah melakukan hal-hal diatas atau kegiatan mengevaluasi.

Menurut Ariely dan Zauberman (dalam Etta mamang sangadji, Sopiah, 2013 : 8) "Perilaku konsumen merupakan tindakan-tindakan yang dilakukan oleh individu, kelompok, atau organisasi yang berhubungan dengan proses pengambilan keputusan untuk mendapatkan, menggunakan barang-barang, atau jasa ekonomis yang dapat dipengaruhi lingkungan."

Lamb et al (dalam Etta mamang sangadji, Sopiah, $2013: 8$ ) mendefinisikan perilaku konsumen sebagai "proses seseorang pelanggan untuk membuat keputusan pembelian, juga untuk menggunakan dan membuang barang dan jasa yang dibeli, termasuk faktorfaktor yang memengaruhi keputusan pembelian dan penggunaan produk."

\section{Strategi Pemasaran}

Menurut Kotler \& Keller (2009: 35) unsur utama proses manajemen pemasaran adalah strategi dan rencana pemasaran yang mendalam dan kreatif yang dapat memandu kegiatan pemasaran. Pengembangan strategi pemasaran yang benar sepanjang waktu memerlukan bauran disiplin dan fleksibilitas. Perusahaan harus tetap berpegang pada strategi, tetapi juga menemukan cara baru untuk terus mengembangkannya. Pemasaran juga harus selalu meningkatkan strategi untuk sejumlah produk dan jasa di dalam organisasinya. Sebagai pemasar bisnis ke bisnis yang sangat sukses.

Menurut Kotler dan Amstrong dalam Nasution (2014) strategi pemasaran adalah pola pikir pemasaran yang akan digunakan oleh unit bisnis untuk mencapai tujuan pemasarannya. Strategi tersebut berisi strategi spesifikasi untuk pasar sasaran, penetapan posisi, bauran pemasaran dan besarnya pengeluaran pemasaran. Proses pemasaran dimulai dari menemukan apa yang diinginkan oleh konsumen. Pemasaran memiliki tujuan yaitu :

1) Konsumen potensial mengetahui secara detail produk yang kita hasilkan dan perusahaan dapat menyediakan semua permintaan mereka atas produk yang dihasilkan;

2) Perusahaan dapat menjelaskan secara detail semua kegiatan yang berhubungan dengan pemasaran. Kegiatan pemasaran ini meliputi berbagai kegiatan, mulai dari penjelasan mengenai produk, desain produk, promosi produk, pengiklanan produk, komunikasi kepada konsumen, 
sampai pengiriman produk agar sampai ke tangan konsumen secara cepat;

3) Mengenal dan memahami konsumen sedemikian rupa sehingga produk cocok dengannya dan dapat terjual dengan sendirinya.

Pada umumnya kegiatan pemasaran berkaitan dengan koordinasi beberapa kegiatan bisnis. Strategi pemasaran ini dipengaruhi oleh faktor-faktor sebagai berikut :

1) Faktor mikro, yaitu perantara pemasaran, pemasok, pesaing dan masyarakat;

2) Faktor makro, yaitu demografi/ ekonomi, politik/hukum, teknologi/fisik dan sosial/budaya.

Menurut Arumsari, Dheany (2012:3) strategi pemasaran terdiri dari unsurunsur pemasaran yang terpadu (4P, yaitu product, price, promotion, place) yang selalu berkembang sejalan dengan gerak perusahaan dan perubahan-perubahan lingkungan pemasaran serta perubahan perilaku konsumen. Perilaku konsumen mempunyai implikasi sangat luas terhadap perumusan strategi pemasaran. Hal ini disebabkan karena strategi pemasaran menyangkut dua kegiatan pokok yang diantaranya adalah pemilihan pasar-pasar yang akan dijadikan sasaran pemasaran, serta merumuskan dan menyusun suatu kombinasi yang tepat dari marketing mix agar kebutuhan konsumen dapat dipenuhi secara memuaskan.

\section{Loyalitas Merek}

Menurut Aaker dalam Rizan, dkk (2012), mendefinisikan loyalitas merek merupakan suatu ukuran keterkaitan pelanggan terhadap sebuah merek. Ukuran ini mampu memberikan gambaran tentang kemungkinan seorang pelanggan beralih ke produk lain terutama pada suatu merek tersebut didapatinya adanya perubahan, baik menyangkut harga atau atribut lain.

Komitmen yang dipegang teguh untuk membeli ulang atau berlangganan dengan produkatau jasa yang disukai secara konsisten di masa mendatang, sehingga menimbulkanpembelian merek yang sama secara berulang meskipun pengaruh situasional dan upaya pemasaran berpotensi menyebabkan perilaku beralih merek (Tjiptono, 2005:387).

Loyalitas memiliki tingkatan sebagaimana dapat dilihat pada piramida loyalitas berikut ini :

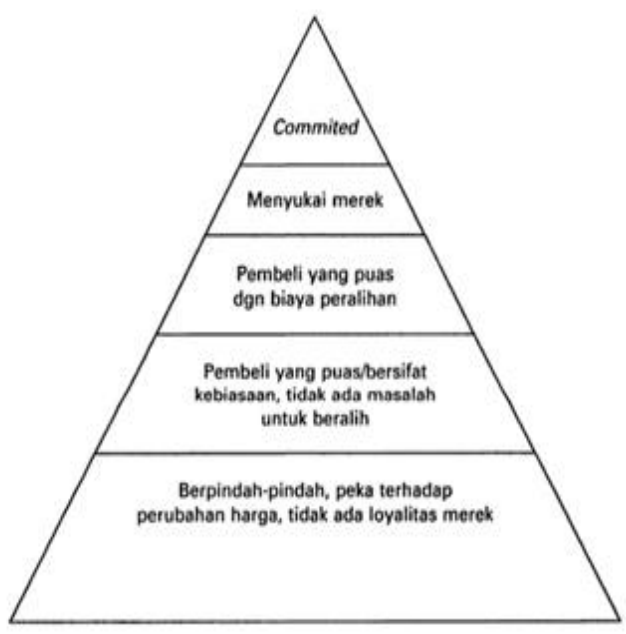

\section{Gambar 1}

Piramida Loyalitas Merek

Sumber: Freddy Rangkuti. The Power of Brands Teknik Mengelola Brand Equity dan Strategi Pengembangan Merek (Jakarta: Gramedia Pustaka Utama, 2002) yang dikutip dari Kusuma (2014: 17)

Berdasarkan piramida loyalitas di atas, dapat dijelaskan bahwa:

a) Tingkat loyalitas yang paling dasar adalah pembeli tidak loyal ayau sama sekali tidak tertarik pada merek-merek apapun yang ditawarkan. Dengan demikian, merek memainkan peran yang kecil dalam keputusan pembelian. Pada umumnya, jenis konsumen seperti ini suka berpindah-pindah merek atau disebut tipe konsumen switcher atau price buyer (konsumen lebih 
memperhatikan harga di dalam melakukan pembelian).

b) Tingkat kedua adalah para pembeli merasa puas dengan produk yang digunakan, atau minimal ia tidak mengalami kekecewaan. Pada dasarnya, tidak terdapat dimensi ketidakpuasan yang cukup memadai untuk mendorong suatu perubahan, terutama apabila pergantian ke merek lain memerlukan buat tambahan biaya. Para pembeli tipe ini dapat disebut pembeli tipe kebiasaan (habitat buyer).

c) Tingkat ketiga berisi orang-orang yang puas, namun mereka memikul biaya peralihan, baik dalam waktu, uang atau resiko sehubungan dengan upaya untuk melakukan pergantian ke merek lain. Kelompok ini biasanya disebut dengan konsumen loyal yang merasakan adanya suatu pengorbanan apabila ia melakukan pergantian ke merek lain. Para pembeli tipe ini disebut satisfied buyer.

d) Tingkat keempat adalah konsumen benar-benar menyukai merek tersebut. Pilihan konsumen terhadap suatu merek dilandasi pada suatu asosiasi, seperti symbol. Rangkaian pengalaman dalam menggunakannya, atau kesan kualitas yang tinggi. Para pembeli tingkat ini disebut sahabat merek, karena terdapat perasaan emosional dalam menyukai merek.

e) Tingkat teratas adalah para pelanggan yang setia. Mereka mempunyai suatu kebanggaan dalam menemukan atau menjadi pengguna satu merek. Merek tersebut sangat penting bagi mereka baik dari segi fungsinya, maupun sebagai ekspresi mengenai siapa mereka sebenarnya.

Menurut Aaker dalam Azman (2011: 43) terdapat lima pengukuran brand loyalty terhadap suatu merek oleh konsumen, adapun pengukuran tersebut adalah sebagai berikut :
a.Behaviour measures (pengukuran perilaku) Suatu cara langsung untuk menetapkan loyalitas terutama untuk habitual behaviour (perilaku kebiasaan) adalah dengan memperhitungkan pola pembelian yang aktual. Berikut beberapa ukuran yang dapat digunakan:

1)Repurchase rate (tingkat pembelian ulang), yaitu tingkat persentase pelanggan yang membeli merek yang sama pada kesempatan membeli jenis produk tersebut.

2)Percent of purchase(persentase pembelian), yaitu tingkat persentase pelanggan untuk setiap merek yang dibeli dari beberapa pembelian terakhir.

3)Number of brands purchase (jumlah merek yang dibeli), yaitu tingkat persentase pelanggan dari suatu produk untuk hanya membeli satu merek, dua merek, tiga merek, dan seterusnya.

Loyalitas pelanggan sangat bervariasi diantara beberapa kelas produk, tergantung pada jumlah merek yang bersaing dan karakteristik produk tersebut. Data mengenai prilaku walaupun obyektif tetap saja keterbatasan dalam kaitannya dengan kompleksitas ataupun biaya perolehannya.

a)Measuring switching cost (pengukuran biaya peralihan)

Pengukuran terhadap variabel ini dapat mengidentifikasikan loyalitas pelanggan terhadap suatu merek. Pada umumnya jika biaya untuk berganti merek sangat mahal, pelanggan akan enggan untuk berganti merek sehingga laju penyusutan kelompok pelanggan dari waktu ke waktu akan rendah.

b)Measuring satisfaction (pengukuran kepuasan)

Pengukuran terhadap kepuasan maupun ketidakpuasan pelanggan suatu merek merupakan indikator penting dari brand loyalty. Bila ketidakpuasan pelanggan suatu merek rendah, maka pada unmunnya tidak cukup alasan bagi 
pelanggan untuk beralih mengkonsumsi merek lain kecuali bila ada faktor-faktor penarik yang sangat kuat. Dengan demikian sangat perlu bagi perusahaan untuk mengeksplor informasi dari pelanggan yang memindahkan pembeliannya ke merek lain dalam kaitannya dengan permasalahan yang dihadapi pelanggan ataupun alasan yang terkait dengan ketergesaan mereka memindahkan pilihannya.

c)Measuring liking the brand (pengukuran kesukaan terhadap merek)

Kesukaan terhadap merek, kepercayaan, perasaan-perasaan hormat atau bersahabat dengan suatu merek membangkitkan kehangatan dalam perasaan pelanggan. Akan sangat sulit bagi merek lain untuk dapat menarik pelanggan yang sudah mencintai merek hingga pada tahapan ini. Pelanggan dapat saja sekedar suka pada suatu merek dengan alasan yang tidak dapat dijelaskan sepenuhnya melalui persepsi dan kepercayaan mereka yang terkait dengan atribut merek. Ukuran dari rasa suka tersebut dapat dicerminkan dengan kemauan membayar harga yang lebih mahal untuk memperoleh merek tersebut.

d)Measuring commitment (pengukuran komitmen)

Salah satu indikator kunci adalah jumlah interaksi dan komitmen pelanggan yang berkaitan dengan produk tersebut. Kesukaan pelanggan terhadap suatu merek akan mendorong mereka untuk membicarakan merek tersebut kepada pihak lain, baik dalam taraf sekedar menceritakan alasan pembelian mereka pada suatu merek atau bahkan tiba pada taraf merekomendasikannya kepada orang lain untuk mengkonsumsi merek tersebut. Indikator lain adalah sejauh mana tingkat kepentingan merek tersebut bagi seseorang berkenan dengan aktivitas dari kepribadian mereka, misalnya manfaat atau kelebihan yang dimiliki dalam kaitannya dengan penggunaan.

\section{Citra Merek}

Menurut Kotler dalam Bastian (2014), citra merek adalah penglihatan dan kepercayaan yang terpendam di benak konsumen, sebagai cerminan asosiasi yang tertahan di ingatan konsumen.

Keller dalam Azman (2011) berpendapat, pengukuran citra merek adalah subjektif, artinya tidak ada ketentuan baku untuk pengukuran citra merek (brand image). Bahwa pengukuran citra merek dapat dilakukan berdasarkan pada aspek sebuah merek yaitu Strengthness, Uniqueness, dan Favorable.

Menurut Tjiptono, Fandy (2005:49) dalam Rizan dan Nopiska (2011) Brand Image atau Brand Description yakni, tentang asosiasi dan keyakinan konsumen terhadap merek tertentu.

Menurut Shamp dalam Radji (2009) yang dikutip dari Bastian (2014), citra merek dapat diukur dari :

1) Atribut

Atribut adalah ciri-ciri atau berbagai aspek dari merek yang diiklankan. Atribut juga dibagi menjadi dua bagian yaitu hal-hal yang tidak berhubungan dengan produk (contoh: harga, kemasan, pemakai, dan citra penggunaan), dan halhal yang berhubungan dengan produk (contoh: warna, ukuran, desain).

2) Manfaat Manfaat dibagi menjadi tiga bagian yaitu fungsional, simbolis, dan pengalaman.

3) Evaluasi keseluruhan

Evaluasi keseluruhan, yaitu nilai atau kepentingan subjektif dimana pelanggan menambahkannya pada hasil konsumen.

Menurut Kotler dalam Rachmawaty, Waty (2014) citra sebagai seperangkat keyakinan, ide, dan kesan yang dimiliki 
seseorang terhadap suatu obyek. Menurut Kotler dan Keller (2008) setiap produk yang terjual dipasaran memiliki citra tersendiri dimata konsumennya yang sengaja diciptakan oleh pemasar untuk membedakannya dari para pesaing mereka.

Menurut Tjiptono dalam Rachmawaty, Waty (2014) brand image adalah deskripsi tentang asosiasi dan keyakinan konsumen terhadap merek tertentu. Selanjutnya, Shimp (2003) mengartikan citra merek adalah sejenis asosiasi yang muncul dibenak konsumenketika mengingat sebuah merek tertentu. Asosiasi tersebut bisa berupa ingatan mengenai merek tersebut. Bisa berupa karakternya, ciri-ciri, kekuatan, bahkan kelemahan merek tersebut.

Kotler dan Keller dalam Kusuma (2014) menyatakan bahwa kepercayaan terhadap merek akan membentuk citra merek dimana citra merek bagi konsumen akan berbeda-beda tergantung pada pengalaman dengan merek tersebut yang disaring oleh efek persepsi selektif, distorsi selektif, dan retensi selektif.

Menurut Kotler \& Keller dalam Sutrisno, Otong (2015) bahwa pengukuran citra merek dapat dilakukan berdasarkan pada aspek sebuah merek, yaitu :

\section{a. Kekuatan (Strengthness)}

Dalam hal ini adalah keunggulan yang dimiliki oleh merek yang bernilai fisik dan tidak ditemukan pada merek lainnya. Keunggulan merek ini mengacu pada atribut-atribut fisik atas merek tersebut sehingga bisa dianggap sebagai sebuah kelebihan dibanding dengan merek lainnya. Yang termasuk pada sekelompok kekuatan (strength) adalah keberfungsian semua fasilitas produk, penampilan fisik, harga produk, maupun penampilan fasilitas pendukung dari produk tersebut dan memiliki cakupan pasar yang luas.

\section{b. Keunikan (Uniqueness)}

Adalah kemampuan untuk membedakan sebuah merek diantara merek lainnya. Kesan ini muncul dari atribut produk tersebut yang menjadi bahan pembeda atau diferensiasi dengan produk-produk lainnya. Yang termasuk dalam kelompok unik ini adalah variasi penampilan atau nama dari sebuah merek yang mudah diingat dan diucapkan, dan fisik produk itu sendiri.

c. Keunggulan (Favorable)

Yang termasuk dalam kelompok favorable ini antara lain, kemudahan merek produk diucapkan serta kemampuan merek untuk tetap diingat oleh pelanggan yang membuat produk terkenal dan menjadi favorit di masyarakat meskipun kesesuaian antara kesan merek di benak pelanggan dengan citra yang diinginkan perusahaan atas merek yang bersangkutan.

Kotler dan Amstrong (2003:285) mendefinisikan citra merek sebagai "Seperangkat keyakinan, ide dan kesan yang dimiliki oleh seseorang terhadap suatu merek". Karena itu sikap dan tindakan konsumen terhadap suatu merek sangat ditentukan oleh citra merek tersebut. Kottler dan Amstrong (2003:285) juga menambahkan bahwa: "Citra merek merupakan syarat dari merek yang kuat". Henry Simamora (2000:72) mengatakan bahwa: "Citra adalah persespsi yang relatif konsisten dalam jangka waktu panjang". Jadi tidak mudah untuk membentuk citra, sehingga bila terbentuk akan sulit untuk mengubahnya. Citra yang dibentuk harus jelas dan memiliki keunggulan bila dibandingan dengan pesaingnya. Saat perbedaan dan keunggulan merek dengan merek lain.

Pandangan konsumen terhadap suatu merek merupakan hal yang sangat 
penting dalam strategi pemasaran. Suatu image dapat membantu perusahaan untuk mengetahui apakah strategi pemasaran yang dijalankan sudah tepat atau belum. Ini berkaitan dengan manfaat brand image dalam suatu perusahaan, yaitu :

1. Dapat dibuat sebagai suatu tujuan dalam strategi pemasaran.

2. Dapat dipakai sebagai suatu dasar untuk bersaing dengan brand-brand lain.

3. Dapat membantu memperbaharui penjualan suatu brand.

4. Dapat digunakan untuk mengevaluasi efek kualitas strategi pemasaran.

5. Dapat dihasilkan dari faktor-faktor lain di luar usaha-usaha strategi pemasaran.

Shimp et al (dalam Etta mamang sangadji, Sopiah, 2013 : 326), citra merek (brand image) dapat dianggap sebagai jenis asosiasi yang muncul di benak konsumen ketika mengingat sebuah merek tertentu. Asosiasi tersebut secara sederhana dapat muncul dalam bentuk pemikiran atau citra tertentu yang dikaitkan dengan suatu merek, sama halnya ketika kita berpikir mengenai orang lain. Berdasarkan pendapatpendapat yang telah disampaikan, dapat disimpulkan bahwa citra merek dapat positif atau negatif, tergantung pada persepsi seseorang terhadap merek (Etta mamang sangadji, Sopiah, 2013 : 327).

\section{Kepercayaan Merek}

Kepercayaan merek adalah persepsi akan kehandalan dari sudut pandang konsumen didasarkan pada pengalaman, atau lebih pada urutan-urutan transaksi atau interaksi yang dicirikan oleh terpenuhinya harapan akan kinerja produk dan kepuasan (Riset Costabile dalam Ferinnadewi, 2008). Kepercayaan terbangun karena adanya harapan bahwa pihak lain akan bertindak sesuai dengan kebutuhan dan keinginan konsumen(Rizan dkk, 2012).

Delgado dalam Ferrinadewi yang dikutip dari Bastian (2014) mengatakan kepercayaan merek adalah kemampuan merek untuk dipercaya (brand reliability), yang bersumber pada keyakinan konsumen bahwa produk tersebut mampu memenuhi nilai yang dijanjikan dan intensi baik merek (brand intention) yang didasarkan pada keyakinan konsumen bahwa merek tersebut mampu mengutamakan kepentingan konsumen.

Kepercayaan pelanggan pada merek (brand trust) didefinisikan sebagai keinginan pelanggan untuk bersandar pada sebuah merek dengan resiko-resiko yang dihadapi karena ekspektasi terhadap merek itu akan menyebabkan hasil yang positif (Lau dan Leedalam Rizan dkk, 2012).

Dalam konteks pemasaran industri, kepercayaan dibangun dalam hubungan person-to-person. Pemahaman brand trust berbeda dengan kepercayaan interpersonal, karena merek merupakan simbol dan simbol tersebut sulit untuk merespon pelanggan. Untuk memperoleh loyalitas dalam pasar saat ini, pemasar harus memfokuskan pada pembentukan dan pemeliharaan kepercayaan dalam hubungan pelanggan dengan merek.Karakteristik merek, karakteristik perusahaan, dan karakt-eristik hubungan pelanggan dengan merek merupakan prediktor penting kepercayaan pelanggan pada merek, yang pada akhirnya akan mengarah pada loyalitas pelanggan pada merek tersebut (Lau dan Lee, dalam Tjahyadi, R A, 2006)

Ferrinadewi dalam Bastian (2014) mengemukakan, terdapat tiga aktivitas yang dapat dilakukan oleh perusahan untuk menumbuhkan kepercayaan konsumen yaitu : 


\section{Achieving result}

Yaitu harapan konsumen tidak lain adalah janji konsumen yang harus dipenuhi bila ingin mendapatkan kepercayaan konsumen.

2. Acting with integrity

Yaitu bertindak dengan integritas berarti adanya konsistensi antara ucapan dan tindakan dalam setiap situasi. Adanya integritas merupakan faktor kunci bagi salah satu pihak untuk percaya akan ketulusan dan pihak lain.

\section{Demonstrate concern}

Yaitu kemampuan perusahaan untuk menunjukkan perhatiannya kepada konsumen dalam bentuk menunjukkan sikap pengertian konsumen jika menghadapi masalah dengan produk, akan menumbuhkan kepercayaan dengan mereka.

Menurut Kustini dalam Rizan dkk (2012), brand trust dapat diukur melalui dimensi viabilitas (dimension of viability) dan dimensi intensionalitas (dimension of intentionality).

\section{Dimension of Viability}

Dimensi ini mewakili sebuah persepsi bahwa suatu merek dapat memenuhi dan memuaskan kebutuhan dan nilai konsumen. Dimensi ini dapat diukur melalui indikator kepuasan dan nilai (value).

\section{Dimension of Intentionality}

Dimensi ini mencerminkan perasaan aman dari seorang individu terhadap suatu merek. Dimensi ini dapat diukur melalui indikator security dan trust.

\section{METODE PENELITIAN}

Jenis penelitian yang digunakan adalah penelitian kuantitatif. Penelitian ini menganalisa tentang pengaruh dari citra merek dan kepercayaan merek terhadap loyalitas merek produk AQUA. Metode analisis yang digunakan dalam penelitian ini adalah metode deskriptif dan verifikatif.Penelitian ini dimaksudkan untuk menguji hipotesis dengan menggunakan perhitungan statistik. Penelitian ini dilakukan untuk menguji pengaruh variabel bebas terhadap variabel terikat yang diteliti.

Populasi dari penelitiaan ini adalah Konsumen Produk AQUA Di Kelurahan Kuningan yang jumlahnya tidak diketahui.Teknik pengambilan sampling yang digunakan dalam penelitian ini adalah dengan non probability sampling yaitu dengan teknik Purposive Sampling, teknik pengambilan sampel yang didasarkan atas tujuan tertentu (orang yang dipilih betul-betul memiliki kriteria sebagai sampel). Jumlah sampel dalam penelitian ini adalah 100 responden yang merupakan konsumen AQUA di Kelurahan Kuningan yang menggunakan AQUA lebih dari 2 kali.

Dalam penelitian ini digunakan teknik pengumpulan data berupa angket.Pengukuran terhadap variabel dilakukan dengan menggunakan jawaban yang diberikan skor dengan skala tertentu.Skala yang digunakan dalam penelitian ini adalah skala interval. Teknik analisis data yang digunakan dalam penelitian ini adalah regresi linier berganda.Langkah-langkah analisis meliputi validitas dan reliabilitas, uji asumsi klasik, pengujian hipotesis melalui uji $\mathrm{F}$, uji $\mathrm{t}$ dan koefisien determinasi $\left(\mathrm{R}^{2}\right)$.Semua pengujian dalam penelitian ini menggunakan alat ukur berupa program komputerSPSS (Statistical Package for the Social Science) versi 21.0.

\section{HASIL DAN PEMBAHASAN}

\section{Hasil Uji Instrumen}

Uji validitas digunakan untuk mengukur sah atau valid tidaknya suatu kuesioner. 
Tabel 4. Hasil Uji Validitas

\begin{tabular}{|c|c|c|c|c|}
\hline Variabel & $\begin{array}{c}\text { No } \\
\text { Ite } \\
\text { m } \\
\end{array}$ & $\begin{array}{c}\text { Pearson } \\
\text { Correlat } \\
\text { ion }\end{array}$ & $\begin{array}{c}\mathbf{r} \\
\text { Tab } \\
\text { el }\end{array}$ & $\begin{array}{c}\text { Keteran } \\
\text { gan }\end{array}$ \\
\hline \multirow{6}{*}{$\begin{array}{l}\text { Citra } \\
\text { Merek } \\
\left(\mathrm{X}_{1}\right)\end{array}$} & $\mathrm{X}_{1-}$ & $.766^{* * *}$ & 0.16 & Valid \\
\hline & $\begin{array}{c}1 \\
X_{1-} \\
2\end{array}$ & $.721^{* * *}$ & $\begin{array}{r}5 \\
0.16 \\
5\end{array}$ & Valid \\
\hline & $\begin{array}{c}\mathrm{X}_{1-} \\
3\end{array}$ & $.808^{* * *}$ & $\begin{array}{r}0.16 \\
5\end{array}$ & Valid \\
\hline & $\begin{array}{c}\mathrm{X}_{1-} \\
4\end{array}$ & $.860^{* * *}$ & $\begin{array}{r}0.16 \\
5\end{array}$ & Valid \\
\hline & $\begin{array}{c}\mathrm{X}_{1-} \\
5\end{array}$ & $.834^{* *}$ & $\begin{array}{r}0.16 \\
5\end{array}$ & Valid \\
\hline & $\begin{array}{c}\mathrm{X}_{1-} \\
6\end{array}$ & $.852^{* * *}$ & $\begin{array}{r}0.16 \\
5\end{array}$ & Valid \\
\hline \multirow{7}{*}{$\begin{array}{l}\text { Kepercay } \\
\text { aan } \\
\text { Merek } \\
\left(\mathrm{X}_{2}\right)\end{array}$} & $\begin{array}{c}\mathrm{X}_{2} \\
1\end{array}$ & $.819^{* *}$ & $\begin{array}{r}0.16 \\
5\end{array}$ & Valid \\
\hline & $\begin{array}{c}\mathrm{X}_{2} \\
2\end{array}$ & $.840^{* *}$ & $\begin{array}{r}0.16 \\
5\end{array}$ & Valid \\
\hline & $\begin{array}{c}\mathrm{X}_{2} \\
3\end{array}$ & $.845^{* *}$ & $\begin{array}{r}0.16 \\
5\end{array}$ & Valid \\
\hline & $\begin{array}{c}\mathrm{X}_{2} \\
4\end{array}$ & $.812^{* * *}$ & $\begin{array}{r}0.16 \\
5\end{array}$ & Valid \\
\hline & $\begin{array}{c}\mathrm{X}_{2} \\
5\end{array}$ & $.865^{* *}$ & $\begin{array}{r}0.16 \\
5\end{array}$ & Valid \\
\hline & $\begin{array}{c}\mathrm{X}_{2} \\
6\end{array}$ & $.831^{* * *}$ & $\begin{array}{r}0.16 \\
5\end{array}$ & Valid \\
\hline & $\begin{array}{c}\mathrm{X}_{2} \\
7\end{array}$ & $.862^{* * *}$ & $\begin{array}{r}0.16 \\
5\end{array}$ & Valid \\
\hline \multirow{6}{*}{$\begin{array}{l}\text { Loyalitas } \\
\text { Merek } \\
\text { (Y) }\end{array}$} & $\mathrm{Y}_{-}$ & $.816^{* * *}$ & $\begin{array}{r}0.16 \\
5\end{array}$ & Valid \\
\hline & $\mathrm{Y}_{-}$ & $.810^{* * *}$ & $\begin{array}{r}0.16 \\
5\end{array}$ & Valid \\
\hline & $\mathrm{Y}_{-}$ & $.885^{* *}$ & $\begin{array}{r}0.16 \\
5\end{array}$ & Valid \\
\hline & $\mathrm{Y}_{-}$ & $.852^{* *}$ & $\begin{array}{r}0.16 \\
5\end{array}$ & Valid \\
\hline & $\mathrm{Y}_{5}$ & $.827^{* *}$ & $\begin{array}{r}0.16 \\
5\end{array}$ & Valid \\
\hline & $\mathrm{Y}_{-}$ & $.792^{* *}$ & $\begin{array}{r}0.16 \\
5\end{array}$ & Valid \\
\hline
\end{tabular}

Sumber: Hasil Output SPSS Version 21.0, (diolah) tahun 2016

Nilai $r$ hitung lebih besar dari $r$ tabel 0,165 dengan tingkat signifikansi korelasi product momen pearson antara masing-masing pernyataan adalah kurang dari $0,05 \quad(\alpha$ 5\%), dengan demikian indikator pada masing-masing variabel dikatakan valid.
Uji reliabilitas ialah alat untuk mengukur suatu kuesioner yang mempunyai indikator dari variabel atau konstruk. Sebuah kuesioner dinyatakan reliable atau handal jika jawaban seseorang terhadap pernyataan adalah konsisten atau stabildari waktu ke waktu (Ghozali, 2016: 47).

Tabel 5

Hasil Uji Reliabilitas

Reliability Statistics

\begin{tabular}{|l|r|r|r|}
\hline \multicolumn{1}{|c|}{ Uariabel } & $\begin{array}{c}\text { Cronb } \\
\text { ach's } \\
\text { Alpha }\end{array}$ & $\begin{array}{c}\text { Cronbach's } \\
\text { Alpha Based on } \\
\text { Standardized } \\
\text { Items }\end{array}$ & $\begin{array}{c}\text { N of } \\
\text { Items }\end{array}$ \\
\hline Citra Merek(X1) & .893 & .893 & 6 \\
\hline $\begin{array}{l}\text { Kepercavaan Merek } \\
\text { X2) }\end{array}$ & .938 & .939 & 8 \\
\hline Loxalitas Merek(Y) & .910 & .910 & 6 \\
\hline
\end{tabular}

Sumber: Hasil Output SPSS Version 21.0, (diolah) tahun 2016

Dengan melihat hasil perhitungan diatas diperoleh nilai $r_{11}>0,70$, dengan demikian masing-masing variabel dikatakan reliabel.

\section{Hasil Uji Regresi Linier Berganda}

Uji Regresi Linier Berganda dilakukan untuk melihat adanya pengaruh citra merek dan kepercayaan merek terhadap loyalitas merek.

\section{Tabel 6}

\section{Hasil Regresi Linier Berganda}

\begin{tabular}{|c|c|c|c|}
\hline \multicolumn{4}{|c|}{ Coefficients $^{\mathrm{a}}$} \\
\hline \multirow[t]{2}{*}{ Model } & \multicolumn{2}{|c|}{$\begin{array}{l}\text { Unstandardized } \\
\text { Coefficients }\end{array}$} & $\begin{array}{l}\text { Standardized } \\
\text { Coefficients }\end{array}$ \\
\hline & B & $\begin{array}{l}\text { Std. } \\
\text { Error }\end{array}$ & Beta \\
\hline (Constant) & 5.272 & 3.201 & \\
\hline 1 TOTAL_CM & .207 & .093 & .187 \\
\hline TOTAL_KM & .511 & .063 & .683 \\
\hline
\end{tabular}

a. Dependent Variable: TOTAL_LM

Sumber: Hasil Output SPSS Version 21.0, (diolah) tahun 2016

Dari tabel 6 didapatkan persamaan regresi: $\mathrm{Y}=5,272+0,207 \mathrm{X}_{1}+0,511 \mathrm{X}_{2}$ 
1. Konstanta sebesar 5,272 menyatakan bahwa jika tanpa dipengaruhi citra merek dan kepercayaan merek maka besarnya nilai loyalitas merek dengan konstanta sebesar 5,272.

2. Koefisien regresi 0,207 menyatakan bahwa setiap perbedaan satu satuan point nilai citra merek akan meningkatkan loyalitas merek sebesar 0,207 pada konstanta 5,272.

3. Koefisien regresi 0,511 menyatakan bahwa setiap perubahan satu satuan point kepercayaan merek akanmeningkatkan loyalitas merek sebesar 0,511 pada konstanta 5,272.

\section{Hasil Uji Koefisien Determinasi $\left(\mathbf{R}^{\mathbf{2}}\right)$}

Uji koefisien determinasi $\left(\mathrm{R}^{2}\right)$ dilakukan untuk melihat seberapa jauh kemampuan model dalam menerangkan variasi variabel dependen. Analisis ini digunakan untuk mengetahui seberapa besar pengaruh bersama antara citra merek dan kepercayaan merek terhadap loyalitas merek.

\section{Tabel 7}

\section{Koefisien Determinasi $\left(\mathbf{R}^{2}\right)$}

\begin{tabular}{|c|c|}
\hline \multicolumn{2}{|c|}{ Model Summary $^{\mathbf{b}}$} \\
\hline Model & Adjusted R Square \\
\hline 1 & .682 \\
\hline
\end{tabular}

a. Predictors: (Constant), TOTAL_KM,

TOTAL_CM

b. Dependent Variable: TOTAL_LM

Sumber: Hasil Output SPSS Version 21.0, (diolah) tahun 2016

Dari tabel 7 didapat nilai Adjusted $R$ Square sebesar 0,682 (68,2\%). Ini menunjukkan bahwa dengan menggunakan model regresi yang didapatkan dimana variabel independen citra merek dan kepercayaan merek memiliki pengaruh terhadap variabel dependen loyalitas merek sebesar $68,2 \%$. Sedangkan sisanya $31,8 \%$ dipengaruhi oleh faktor lain yang tidak diteliti oleh peneliti.

\section{Hasil Pengujian Hipotesis a.Uji F (Uji Simultan)}

Uji $F$ atau uji Koefisien secara bersamasama digunakan untuk mengetahui apakah secara bersama-sama variabel independen berpengaruh signifikan terhadap variabel dependen (Priyanto, 2012:137).

\section{Tabel 8}

\section{Hasil Pengujian Simultan (Uji F)}

\begin{tabular}{|cl|c|c|}
\hline Model & & F & Sig. \\
\hline \multirow{2}{*}{1} & $\begin{array}{l}\text { Regression } \\
\text { Residual } \\
\text { Total }\end{array}$ & 107.241 & $.000^{\mathrm{b}}$ \\
& & \\
\hline
\end{tabular}

a. Dependent Variable: TOTAL_LM

b. Predictors: (Constant), TOTAL_KM, TOTAL_CM

Sumber: Hasil Output SPSS Version 21.0, (diolah) tahun 2016

Berdasarkan hasil uji $\mathrm{F}$ pada tabel 8 terlihat bahwa nilai $F_{\text {hitung }}$ sebesar 107,241 dengan tingkat signifikansi 0,000 dan dengan $\mathrm{df}_{1}$ (jumlah variabel-1) $=3-1=2$, dan $\mathrm{df}_{2}(\mathrm{n}-\mathrm{k}-1)=100-2-1=97$, nilai $\mathrm{F}_{\text {tabel }}$ dengan menggunakan tingkat $\alpha$ $=0,05$ atau 5\% adalah 3,09 sehingga $F_{\text {hitung }}>F_{\text {tabel }}(107,241>3,09)$ dan nilai sig $(0,000)<\alpha 0,05$, maka $\mathrm{H}_{0}$ ditolak dan $\mathrm{H}_{\mathrm{a}}$ diterima, sehingga dapat disimpulkan bahwa Citra Merek dan Kepercayaan Merek secara bersamasama (simultan) berpengaruh positif dan signifikan terhadap Loyalitas Merek.

\section{b. Uji t (Uji Parsial)}

Uji t atau uji koefisien regresi secara parsial digunakan untuk mengetahui apakah secara parsial variabel independen berpengaruh secara signifikan atau tidak terhadap variabel dependen. (Priyanto, 2012:139). 
Tabel 9

Hasil PengujianParsial (Uji t)

Coefficients $^{\mathrm{a}}$

\begin{tabular}{|c|c|c|c|}
\hline \multicolumn{2}{|c|}{ Model } & $\mathrm{T}$ & Sig. \\
\hline & (Constant) & 1.647 & .103 \\
\hline 1 & TOTAL_CM & 2.222 & .029 \\
\hline & TOTAL_KM & 8.128 & .000 \\
\hline
\end{tabular}

a. Dependent Variable: TOTAL_LM

Sumber: Hasil Output SPSS Version 21.0, (diolah) tahun 2016

Berdasarkan hasil uji $\mathrm{t}$ pada tabel 9 terlihat bahwa nilai thitung citra merek sebesar 2,222 dengan tingkat signifikansi 0,029 , nilai $t_{\text {tabel }}$ dengan menggunakan tingkat $\alpha=0,05$ atau 5\% adalah 1,660 sehingga $t_{\text {hitung }}>t_{\text {tabel }}(2,222>1,660)$ dan nilai sig $(0,029)<0,05$, maka $\mathrm{H}_{0}$ ditolak dan $\mathrm{H}_{\mathrm{a}}$ diterima, sehingga dapat disimpulkan bahwa Citra Merek berpengaruh positif dan signifikan terhadap Loyalitas Merek. Sedangkan nilai $t_{\text {hitungkepercayaan merek sebesar }}$ 8,128 dengan tingkat signifikansi 0,000 , sehingga $t_{\text {hitung }}>t_{\text {tabel }}(8,128>1,660)$ dan nilai sig $(0,000)<0,05$, maka $\mathrm{H}_{0}$ ditolak dan $\mathrm{H}_{\mathrm{a}}$ diterima, sehingga dapat disimpulkan bahwa Kepercayaan Merek berpengaruh positif dan signifikan terhadap Loyalitas Merek.

\section{PEMBAHASAN}

\section{a.Pengaruh Citra Merek terhadap Loyalitas Merek}

Citra suatu merek akan mempengaruhi konsumen untuk tetap menggunakan suatu produk dengan merek tertentu secara terus menerus karena sekarang ini konsumen banyak mencari produk dengan merek yang sudah terkenal atau dapat dikatakan dengan adanya citra yang kuat dan positif dari suatu merek akan mempermudah perusahaan dalam menarik pelanggan baru dan mempertahankan pelanggan untuk tetap loyal pada satu merek.
Hasil penelitian ini citra merek berpengaruh positif terhadap loyalitas merek produk AQUA karena konsumen akan tetap menggunakan produk dengan citra merek yang terbukti baik dan positif, sebagai jaminan bahwa merek tersebut memberikan yang diharapkan dan memberikan yang terbaik.

\section{b.Pengaruh Kepercayaan Merek terhadap Loyalitas Merek}

Kepercayaan konsumen pada suatu merek akan membuat konsumen memiliki hubungan dengan merek tersebut. Rasa percaya konsumen yang tinggi pada suatu merek, akan menimbulkan harapan yang tinggi pula dari merek tersebut.

Hasil penelitian ini kepercayaan merek berpengaruh positif terhadap loyalitas merek produk AQUA konsumen yang sudah percaya pada suatu merek akan terus melakukan pembelian ulang yang menandakan bahwa konsumen tersebut adalah konsumen yang loyal. Dengan adanya rasa percaya konsumen pada suatu merek, diharapkan bahwa merek tersebut akan memberikan kualitas yang baik.

\section{c.Pengaruh Citra Merek dan Kepercayaan Merek Secara Bersama- sama terhadap Loyalitas Merek}

Citra merek yang baik serta adanya kepercayaan konsumen pada suatu merek akan mempengaruhi pada loyalitas suatu merek. Dengan hasil ini maka dapat disimpulkan bahwa loyalitas merek dipengaruhi oleh citra merek dan kepercayaan merek sebesar 68,2\% sedangkan $31,8 \%$ dipengaruhi oleh faktor lain yang tidak diteliti oleh peneliti. Dari hasil uji analisis dalam penelitian ini, dihasilkan bahwa variabel Citra Merek dan variabel Kepercayaan Merek berpengaruh signifikan secara 
bersama-sama terhadap variabel Loyalitas Merek.

\section{KESIMPULAN DAN SARAN \\ Kesimpulan}

Berdasarkan hasil penelitian dan pembahasaan mengenai pengaruh Citra Merek dan Kepercayaan Merek terhadap Loyalitas Merek produk AQUA, maka dapat ditarik kesimpulan sebagai berikut:

Pertama, citra Merek dan Kepercayaan Merek berpengaruh signifikan terhadap Loyalitas Merek.

Kedua, citra Merek berpengaruh positif dan signifikan terhadap Loyalitas Merek, artinya ketika Citra Merek meningkat maka Loyalitas Merek akan meningkat.

Ketiga, kepercayaan Merek berpengaruh positif dan signifikan terhadap Loyalitas Merek, artinya ketika Kepercayaan Merek meningkat maka Loyalitas Merek akan meningkat.

\section{Saran}

Berdasarkan penelitian yang telah diperoleh dalam penelitian ini, maka peneliti akan memberikan saran yang diharapkan akan menjadi masukan dan bahan pertimbangan bagi perusahaan khususnya para pengusaha di bidang Air Minum Dalam Kemasan (AMDK). saran-saran tersebut ialah sebagai berikut:

Pertama, dari deskripsi jawaban responden terhadap Citra Merek jawaban indikator keunikan masih rendah, maka perusahaan perlu membuat desain merek AQUA yang lebih menarik yang membedakan dari produk kompetitor dan membuat konsumen yakin bahwa AQUA berbeda dengan merek Air Minum Dalam Kemasan lain, sehingga Air Minum Dalam Kemasan merek AQUA mudah dikenali diantara merek lainnya.

Kedua dari deskripsi jawaban responden terhadap Kepercayaan Merek jawaban indikator kepercayaan masih rendah, maka perusahaan perlu menginformasikan cara produksi yang sehat untuk meningkatkan kepercayaan konsumen. Perusahaan sebaiknya meyakinkan konsumen bahwa perusahaan menghasilkan produk yang ramah lingkungan dengan melakukan promosi melalui iklan dan melakukan kegiatan sosial, sehingga konsumen akan mempercayai kualitas merek AQUA yang akan meningkatkan loyalitas pada merek AQUA.

Ketiga, penelitian ini terbatas pada variabel Citra Merek dan Kepercayaan Merek terhadap Loyalitas Merek, masih ada peluang untuk melakukan penelitian dengan variabel lain yang mempengaruhi loyalitas merek misalnya kualitas produk, kepuasan pelanggan dan variabel lain yang belum diteliti dalam penelitian ini, sehingga dapat mengetahui pengaruh variabel lain terhadap loyalitas merek AQUA.

\section{DAFTAR PUSTAKA}

Anwar, A., Gulzar, A., Sohail, F. Bin, \& Akram, S. N. (2011). Impact of Brand Image, Trust and Affect on Consumer Brand Extension Attitude: the Mediating Role of Brand Loyalty. International Journal of Economics and Management Sciences, I(5), 73-79.

Arikunto., Suharsimi. (2002). Prosedur penelitian. Jakarta: Rineka Cipta.

Arumsari, D. (2012). Analisis pengaruh kualitas produk, harga dan promosi terhadap keputusan pembelian air minum dalam kemasan (amdk) merek aqua (studi pada konsumen toko bhakti mart kpri bhakti praja provinsi jawa tengah).Skripsi Universitas Diponegoro Semarang.

Azman, M. N. (2011). Pengaruh harga (price), trust in brand, dan brand image terhadap brand loyalty pada pengguna sepeda motor honda.Skripsi Universitas Islam Negeri Syarif Hidayatullah.

Bastian, D. A. (2014).Analisis Pengaruh Citra Merek (Brand Image) dan Kepercayaan 
Merek (Brand Trust) Terhadap Loyalitas Merek (Brand Loyalty) ADES PT. Ades Alfindo Putra Setia,Jurnal Manajemen Pemasaran Petra 2(1), 1-9

Buchari., Alma. (2013). Manajemen pemasaran dan pemasaran jasa. Bandung: Alfabeta.

Edris, M. (2009).Pengaruh Kepercayaan Merek Terhadap Loyalitas Merek (Studi Kasus pada Detergen Merek Rinso di Kabupaten Kudus). ISSN: 1978-6889.

Etta Mamang Sangadji dan Sopiah, 2013 Perilaku Konsumen, Pendekatan Praktis Disertai Himpunan Jurnal Penelitian, Penerbit Andi Yogyakarta, Edisi 1

Ferdinand, Augusty. 2014. Metode Penelitian Manajemen. Semarang: Badan Penerbit Universitas Diponegoro.

Freddy Rangkuti.The Power of Brands Teknik Mengelola Brand Equity dan Strategi Pengembangan Merek (Jakarta: Gramedia Pustaka Utama, 2002) yang dikutip dari Kusuma (2014: 17)

Ghozali, Iman. 2006. Aplikasi Analisis Multivariate Dengan Program SPSS. Edisi Ketiga. Badan Penerbit Universitas Diponogoro. Semarang.

Ghozali, Imam. 2016. Aplikasi Analisis Multivariete Dengan Program IBM SPSS 23. Semarang: Badan Penerbit Universitas Diponegoro Edisi 8.

Hafizah. 2012. Hubungan Kepercayaan Merek dan Kualitas Produk Telkomsel Flash Terhadap Kepuasan Konsumen di PT. Telkomsel Grapari Medan Selecta.Jurnal Keuangan \& Bisnis, Vol. 4, No. 1, pp. 8297

http://www.aqua.com

http://industri.bisnis.com/(12 Februari 2015)

Kabadayi, E. T., \& Alan, A. K. (2012). Brand Trust and Brand Affect: Their Strategic Importance on Brand Loyalty. Journal of Global Strategic Management, 6(1), 80-88.

Keputusan Menteri Perindustrian Dan Perdagangan Republik Indonesia Nomor : 705/Mpp/Kep/11/2003 Tentang Persyaratan Teknis Industri Air Minum Dalam Kemasan Dan Perdagangannya

Kotler, P \& Keller, K, L (2009).Manajemen Pemasaran, Edisi Ketiga Belas Jilid 1.

Kuncoro, Mudrajat. 2003. Metode Penelitian Untuk Bisnis dan Ekonomi. Jakarta: Erlangga.

Kurnia, S. (2013).Pengaruh Persepsi Efek Corporate Social Responsibility (CSR) Terhadap Loyalitas Pelanggan Air Minum Dalam Kemasan (AMDK) Merek AQUA
(Survei Pada Peserta Danone Nations Cup 2013 Di Kota Bandung).Repository.upi.edu.

Kurniati, A.D., Farida, N., \& Nurseto, S. (2012). Pengaruh Kesadaran Merek Dan Persepsi Kualitas Terhadap Loyalitas Merek Melalui Kepercayaan Merek Sebagai Variabel Intervening Pada Ponsel Nokia (Studi pada mahasiswa Fakultas Ilmu Sosial dan Ilmu Politik Universitas Diponegoro), 1-9.

Kusuma, R. A. (2014). Analisis Pengaruh Citra Merek Dan Kepercayaan Merek Terhadap Ekuitas Merek Melalui Loyalitas Merek Sebagai Variabel Intervening (Studi Pada Perokok Anak Muda Di Kota Semarang).Skripsi Universitas Diponegoro Semarang.

Nasution, S.W.P. 2014. Bab II Kerangka Teoritis. Responsuri USU.

Nazir, M. 2006. Metode Penelitian. Jakarta: Ghalia Indonesia

Peraturan Menteri Kesehatan Republik Indonesia Nomor 492/Menkes/Per/Iv/2010 Tentang Persyaratan Kualitas Air Minum

Peraturan Menteri Perindustrian Republik Indonesia Nomor 49/M-Ind/Per/3/2012 Tentang Pemberlakuan Standar Nasional Indonesia (SNI) Air Minum Dalam Kemasan (AMDK) Secara Wajib

Pratiwi, D. M., Saerang, D. P. E., \& Tumewu, F. (2015). The Influence Of Brand Image, Brand Trust And Customer Satisfaction On Brand Loyalty (Case Of Samsung Smartphone), 15(05), 377-385.

Priyanto, D. 2012. Cara Kilat Belajar Analisis Data dengan SPSS 20. Yogyakarta: Andi Offset.

Priyatno, Dwi. 2009. Belajar Analisis Data dengan SPSS 20. Yogyakarta: Andi.

Rachmawati, W. 2014.Pengaruh Citra Merek Dan Kualitas Produk Terhadap Keputusan Pembelian Bedak Inez Di Kuningan (Survei pada Toserba Fajar Luragung). Skripsi Fakultas Ekonomi Universitas Kuningan.

Rini, A. S. \& Sulistyawati, E. (2014).Pengaruh Brand Trust, Customer Satisfaction, Dan Corporate Social Responsibility Terhadap Brand Loyalty Fakultas Ekonomi dan Bisnis Universitas Udaya (Unud), Bali, Indonesia, 510-529

Rizan, M \& Nopiska, Y. (2011).Pengaruh Citra Dan Kepercayaan Merek Terhadap Loyalitas Merek. 
Rizan, M., Saidanni, B., \& Sari, Y. (2012).Pengaruh Brand Image Dan Brand Trust Terhadap Brand Loyalty Teh Botol Sosro, 3(1), 1-17

Saladin, Djaslim. 2006. Manajemen Pemasaran Analisis, Perencanaan, Pelaksanaan dan Pengendalian. Bandung: CV Linda Karya.

Saleem, S., Rahman, S. U., \& Omar, R. M. (2015). Conceptualizing and Measuring Perceived Quality, Brand Awareness, and Brand Image Composition of Brand Loyalty, International Journal of Marketing Studies, 7(1), 66-77.

Sarjono, H \& Julianita, W. 2013.SPSS VS LISREL Sebuah Pengantar, Aplikasi Untuk Riset Cetakan Kedua. Jakarta: Salemba Empat.

Sudijono, Anas. 2009. Pengantar Statistik Pendidikan. Jakarta: Rajawali Pers.

Sugiyono.2012. Metode Penelitian Kuantitatif, Kualitatif, Dan Kombinasi (Mixed Methods). Bandung: ALFABETA, CV.

Suliyanto. 2011. Ekonomi Terapan: Teori \& Aplikasi Dengan SPSS. Yogyakarta: Andi Publisher.

Sutrisno, Otong. 2015. Pengaruh Kualitas Produk Dan Citra Merek Terhadap Keputusan Pembelian Smartphone Samsung (Penelitian pada Mahasiswa Fakultas Ekonomi Universitas Kuningan).
Skripsi Fakultas Ekonomi Universitas Kuningan.

Taufandra, M \& Rahanatha, I. G. B. Pengaruh Citra Merek Terhadap Persepsi Kualitas Dan Loyalitas Merek, 3342-3356.

Tingkir, C. F. (2014). Pengaruh Identitas Merek Terhadap Loyalitas Merek Melalui Citra Merek Dan Kepercayaan Merek Toyota, Jurnal Manajemen Pemasaran.8(2), 62-69.

Tjahjaningsih, E \& Yuliani, M. (2007).Pengaruh Kesadaran Merek Dan Persepsi Kualitas Terhadap Loyalitas Merek Melalui Kepercayaan Merek HP Nokia, 104-118.

Tjahyadi, R. A. (2006). "Brand Trust Dalam Konteks Loyalitas Merek: Peran Karakteristik Merek, Karakteristik Perusahaan dan Karakteristik Hubungan Pelanggan Merek", Jurnal Manajemen, 6 (1).

Tjiptono, Fandy. 2005. Brand Management and Strategy. Yogyakarta: Andi Publisher.

UU No 8 Tahun 1999 Tentang Perlindungan Konsumen

Wulan, A., Ep, A., \& Nuseto, S. (2014). Loyalitas Merek Melalui Kepercayaan Merek Sebagai Variabel Intervening Pada Notebook Toshiba (Studi Pada Mahasiswa Universitas

Diponegoro Semarang).Diponegoro Journal Of Social And Political Science 